\title{
The Trends in Structural Aspect of Work in Contemporary Architecture
}

\section{Tendence současné architektury ve strukturálním pojetí díla}

\author{
Daniel Kuda \\ Ústav stavitelství, Fakulta architektury, Vysoké učení technické v Brně \\ školitel: doc. Ing. Monika Petřričková, Ph.D.
}

\begin{abstract}
Architecture is evolving like any other industry, and because architectural work is the synthesis of science and art, the key role in its development is played by new technologies, processes and materials as well as the contemporary concept of space, the ideals of beauty and the spirit of the times. Progressive architectural works often depend only on the architect's sense of the tangible and intangible parts of the design and ability to harmonize them. When analyzing the structure and architectural space of these structures, it is possible to trace certain directions, which then develop further while the basic principle remains preserved. This paper is concerned with "gridshell" structures whose support systems are wood-based. From the results we can deduce some basic features characteristic of the material, and then predict future development and design new spatial and structural forms.
\end{abstract}

KEYWORDS: gridshell; grate structure; wood; progressive architecture; architectural space

\begin{abstract}
ABSTRAKT: Architektura se jako každý jiný obor vyvíjí, a protože architektonické dílo je syntézou vědy a umění, klíčovou roli v jejím vývoji hrají jak nové technologie, postupy a materiály, tak současné pojetí prostoru, ideálů krásy a ducha doby. U progresívních architektonických děl mnohdy záleží jen na citu architekta pro hmotné a nehmotné ćásti návrhu a jeho schopnosti je harmonizovat. Při analýzách struktury a architektonického prostoru těchto staveb lze vysledovat určité směry, které se pak dále rozvíjejí, přičemž základní princip zůstává zachován. Tato práce se věnuje roštovým konstrukcím („gridshell“), jejichž nosný systém je na bázi dřeva. Na základě výsledků lze vyvodit určité základní rysy charakteristické pro daný materiál a následně
\end{abstract}


predikovat budoucí vývoj a navrhnout nové prostorové a strukturální formy.

KLÍČOVÁ SLOVA: gridshell; roštová konstrukce; dřevo; progresívní architektura; architektonický prostor

\section{Úvod}

Tento článek prezentuje část zkoumání věnujícího se progresívním konstrukcím na bázi dřeva. Konkrétně se věnuje roštovým konstrukčním systémům nazývaným gridshell. Tyto struktury slavily svoje zlatá léta v první polovině 19. století, ale postupně byly z důvodu náročnosti statických výpočtů opouštěny. Dnes již moderní výpočetní technologie umožňují vytvářet detailní statické modely nepravidelných struktur. Samotná forma a návrh nosné struktury vznikají pomocí parametrického navrhování. Korekce dle statických požadavků dále probíhají na základě matematických změn zadaných parametrů. Tímto postupem lze dosáhnout optimálního tvaru a vysoce efektivního rozložení materiálu ve struktuře. Do výzkumu byly zařazeny i experimentální konstrukce, sledující jen některé aspekty konstrukčního systému na úkor jiných.

\section{Dřevo}

Dřevo je pevné pletivo stonků vyšších rostlin, které nazýváme dřeviny. Jedná se o biomasu, obnovitelný zdroj energie a také stavební materiál. Je snadno dostupné, jednoduše zpracovatelné a vyznačuje se zápornou uhlíkovou stopou (při růstu stromu dochází ke spotřebě $\mathrm{CO}_{2}$ ). $\mathrm{Z}$ těchto důvodů se jedná o materiál, který lidstvo využívá po celou dobu své existence.

V souvislosti s technologickým pokrokem došlo ve stavebnictví a architektuře k objevení a využívání nových materiálů, které dřevo částečně nebo úplně nahradily. Dřevo má svá omezení a v současné progresívní architektuře by se mohlo zdát, že už jsou jeho možnosti vyčerpány.

Pro účely zkoumání byly vybrány stavby s konstrukčním systémem na bázi dřeva, které vznikly během posledních patnácti let. Architektura a stavebnictví obecně jsou vždy pozadu za technologickým a uměleckým pokrokem. Vyprojektovat stavbu a následně ji postavit (nehledě na povolovací proces) zabere mnoho času, a proto je patnáctileté období považováno za optimální časové rozmezí.

\section{"Gridshell"}

Pro další analýzu staveb je třeba si nejprve definovat konstrukce nazývané gridshell (z anglických slov grid - rastr nebo mříž a shell - skořepina). Jsou to obvykle dvojitě zakřivené 
struktury, které jsou vytvořeny z rámů nebo žeber tvořících rastr. Rastr nemusí být v půdorysu ortogonální, mnoho staveb experimentuje s méně či více nepravidelnými mřížkami. Průběh sil v konstrukci záleží na celkovém tvaru struktury, lze vytvořit takové systémy, jejichž zatížení bude prakticky výhradně tlakové (obdobně jako u betonových skořepin).

Za první strukturu typu gridshell je považován výstavní pavilon na Všeruské umělecko-průmyslové výstavě v Nižním Novgorodě v roce 1896 od ruského inženýra Vladimira Grigorjeviče Šuchova. Jednalo se o ocelovou konstrukci, a i když je pro gridshell ocel stále využívána, nejčastěǰ̌ím materiálem současných staveb je dřevo. Postup výstavby je v zásadě trojí. První možností je vytvoření rastru v rovině a jeho následná deformace do zamýšlené zakřivené formy. Druhou možností je ukládání jednotlivých prvků po částech na dočasnou podpůrnou konstrukci. Poslední variantou je vyřezání jednotlivých rámů skořepiny (charakterizovány jako $2 \mathrm{D}$ řezy se stejným rozestupem) a jejich následné pospojování. Podpůrná konstrukce ani dodatečné deformace zde nejsou potřeba.

Autobahnkirche Siegerland (dálniční kostel Siegerland)

Schneider + Schumacher Verwaltungsgesellschaft mbH

Wilnsdorf, Německo

2013

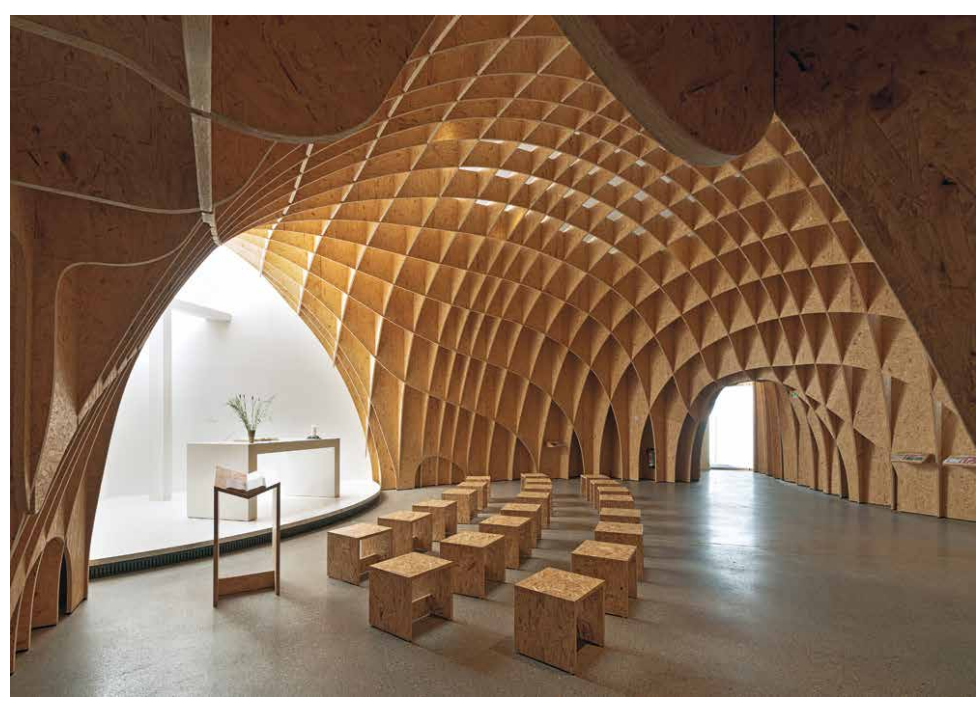

Obr. 1. Interiér stavby (Zdroj: http://www.schneider-schumacher.com/projects/project-details/39-autobahn-church-siegerland.project?tx_vierwdsusprojects_pi1[controller] $=$ Project\&cHash=09d742f14a958b6da353cd82292ecfbe [cit. 2018-08-30])

Nosná konstrukce kostela je tvořena ortogonální roštovou konstrukcí (gridshell) 
z OSB desek. „Skořepina“ se skládá z 650 samostatných dílů, které byly vyrobeny na CNC fréze. Konstrukce je dohromady pospojována pomocí drážek v deskách, $\mathrm{k}$ fixaci byly použity pouze bodově ocelové úhelníky.

Tento typ konstrukce umožňuje poměrně jednoduchou organickou tvorbu architektonického prostoru. Zamýšlená 3D skořepina je napřed vymodelována na počítači jako jednolitá a následně jsou vytvořeny řezy v určené osové vzdálenosti ve dvou na sebe kolmých směrech. Výsledkem je množina 2D ploch, jejichž spojením vznikne výsledná konstrukce. Výroba i montáž jednotlivých prvků jsou značně jednodušší než tvorba bednění a následné odlití struktury např́klad z betonu. Výsledná konstrukce se vyznačuje mimořádnou tuhostí, lehkostí a subtilností. Velkou výhodou je možnost prosvětlení interiéru objektu osazením bud' kompletního transparentního pláště, nebo okenních otvorů do výsledného rastru.

Vztah vnitřního prostoru a venkovního objemu se vyznačuje značnou nezávislostí, ve své podstatě se jedná o formu „barokního dualismu“. Na obrázku je fotografie vnější formy.

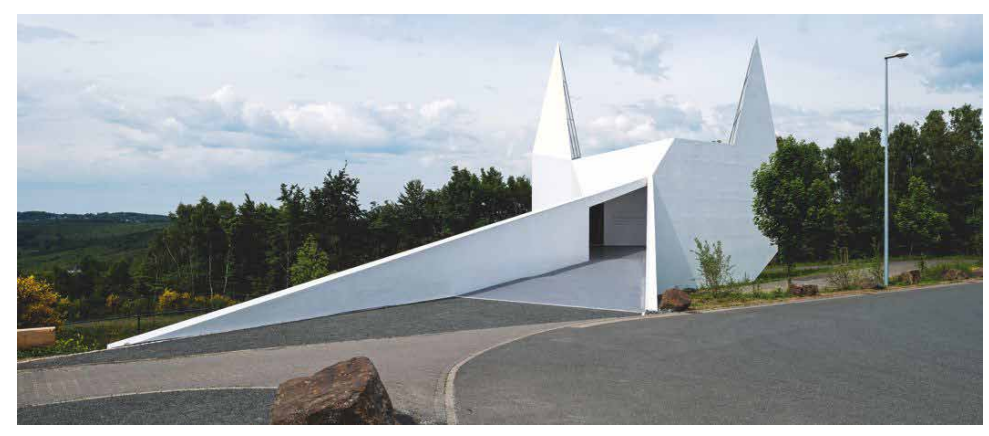

Obr. 2. Exteriér (Zdroj: http://www.schneider-schumacher.com/projects/project-details/39-autobahn-church-siegerland.project?tx_vierwdsusprojects_pi1[controller] $=$ Project $\&$ cHash=09d742f14a958b6da353cd82292ecfbe [cit. 2018-08-30])

\section{Metropol Parasol}

Jürgen Mayer $\mathrm{H}$.

Plaza de la Encarnación, Sevilla, Španělsko 2007

Stavba umístěná na náměstí v centru historického města Sevilla, která se stala jeho ikonou, je přibližně 150 metrů dlouhá, 75 metrů široká a 28 metrů vysoká, čímž mírně převyšuje okolní zástavbu. Tato ojedinělá urbánní struktura, připomínající 
obří houby, obsahuje v suterénu archeologické muzeum, v úrovni ulice kryté tržiště, na mírně zvýšeném pódiu prostor pro konání veřejných akcí a bar s restaurací a v horní části (včetně střechy) se nachází panoramatický chodník.

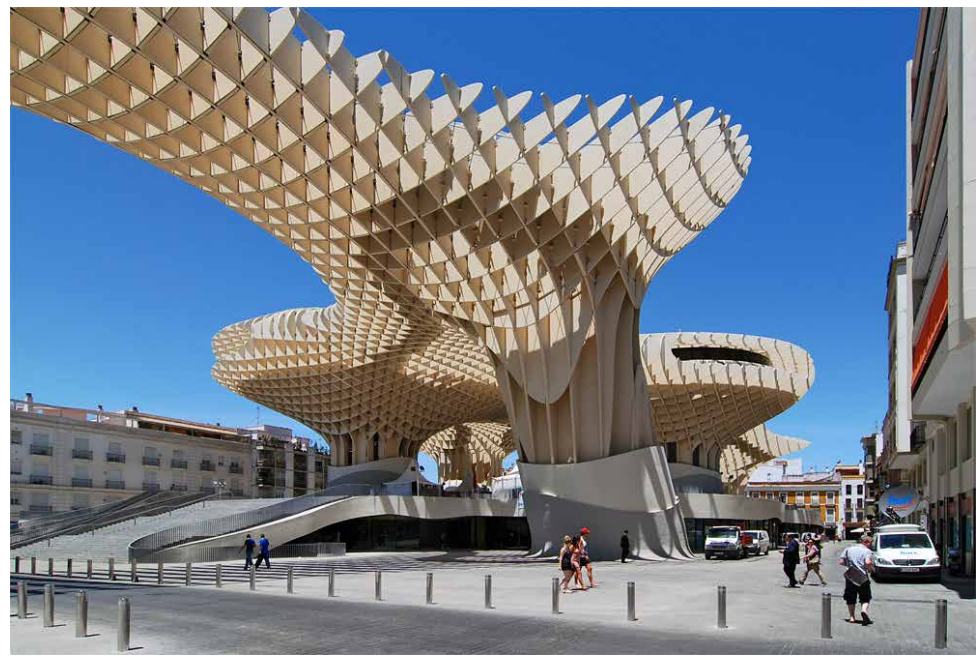

Obr. 3. Celkový pohled na stavbu (Zdroj: https://www.archiweb.cz/b/metropol-parasol [cit. 2018-08-30])

Princip využití ortogonální roštové konstrukce je obdobný jako u dálničního kostela. Jedná se o tuhý obousměrný dřevěný rošt, který tvoří více než 3000 nepravidelných dvourozměrných prvků, které jsou sestaveny do ortogonální sítě o modulu $1,5 \times 1,5$ metru. Výška jednotlivých nosníků je různá dle zatížení, od 30 centimetrů na okrajích až po tři metry u napojení na svislé části. Liší se i tlouštka panelů, stanovená na základě počítačové simulace statiky, a to od 7 po $22 \mathrm{~cm}$. Ztužení je realizováno pomocí ocelových táhel, která se nacházejí pod panoramatickým chodníkem.

Nosnou konstrukci nekryje střecha, proto byl pro ochranu materiálu před povětrnostními vlivy použit nový způsob impregnace dřeva - dřevo je přímo natřené voděodolným a současně paropropustným polyuretanovým nátěrem $\mathrm{v}$ tlouštce $\mathrm{dva}$ až tři milimetry.

Ortogonální roštová konstrukce umožňuje vytvořit ojedinělou, několikapodlažní urbánní strukturu. Konstrukci lze díky její transparentnosti a relativní subtilnosti využít pro překrytí i takové plochy, jakou je náměstí Plaza de la Encarnación, bez ohrožení prosvětlenosti a prosluněnosti prostoru pod Parasolem. Je důležité si uvědomit rozdílnost jednotlivých pohledů, přičemž boční pohledy jsou plné - nepropustné, čímž vyniká hmota objektu, půdorys je pouze subtilní mřížovinou. 


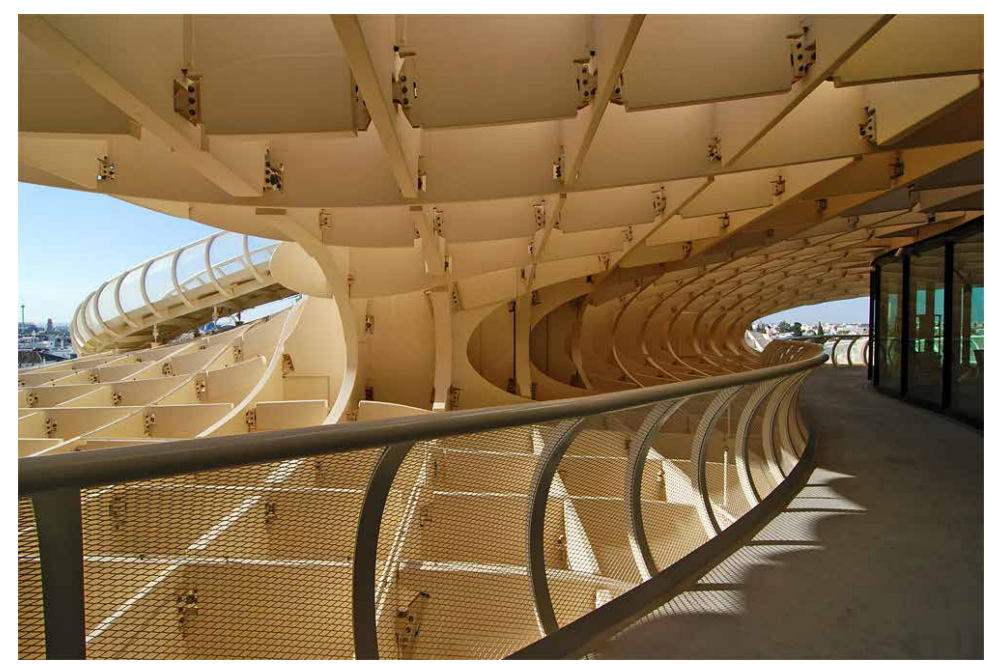

Obr. 4. Konstrukce (Zdroj: https://www.archiweb.cz/b/metropol-parasol [cit. 2018-08-30])

\section{Country club Nine Bridges}

Shigeru Ban Architects

Yeoju-gun, provincie Kjonggi, Jižní Korea

2009

Objekt luxusního golfového klubu se skládá ze tří staveb: hlavní objekt pro řadové členy klubu, objekt pro VIP a ubytování pro VIP hosty. Každá z těchto staveb je navržena v odlišném konstrukčním systému, který je moderní aplikací tradičních jihokorejských stavebních metod.

Pozoruhodná je zejména konstrukce vstupního atria objektu pro řadové členy klubu. Jedná se o konstrukci typu gridshell tvořenou ohýbanými lepenými dřevěnými lamelami. Architektonická forma vznikla nekonečným zakřivením 2D plochy v bodech sloupů. Ve své podstatě se jedná o třídimenzionální přepis zakřivení prostoru okolo hmotných těles ve vesmíru. $2 \mathrm{D}$ plochu tvoří hexagonální mřížka, ze které lamely volně přecházejí do podpor. Dřevěná struktura podporuje ocelovou konstrukci střechy s prosvětlovacími otvory nad osami sloupů. Stěny objektu tvoří transparentní skleněné fasády.

Princip organické sítě tvořené lepenými lamelami je pro architekturu od Šigerua Bana typický. Obdobný princip použil u Centre Pompidou-Metz, kde je lamelová skořepina př́mo zakrytá průsvitnými deskami a odpadá tak mezistupeň v ocelové konstrukci stř̌echy. Šigeru Ban postupně zavedl nový typ zakřiveného plynoucího architektonického prostoru. 


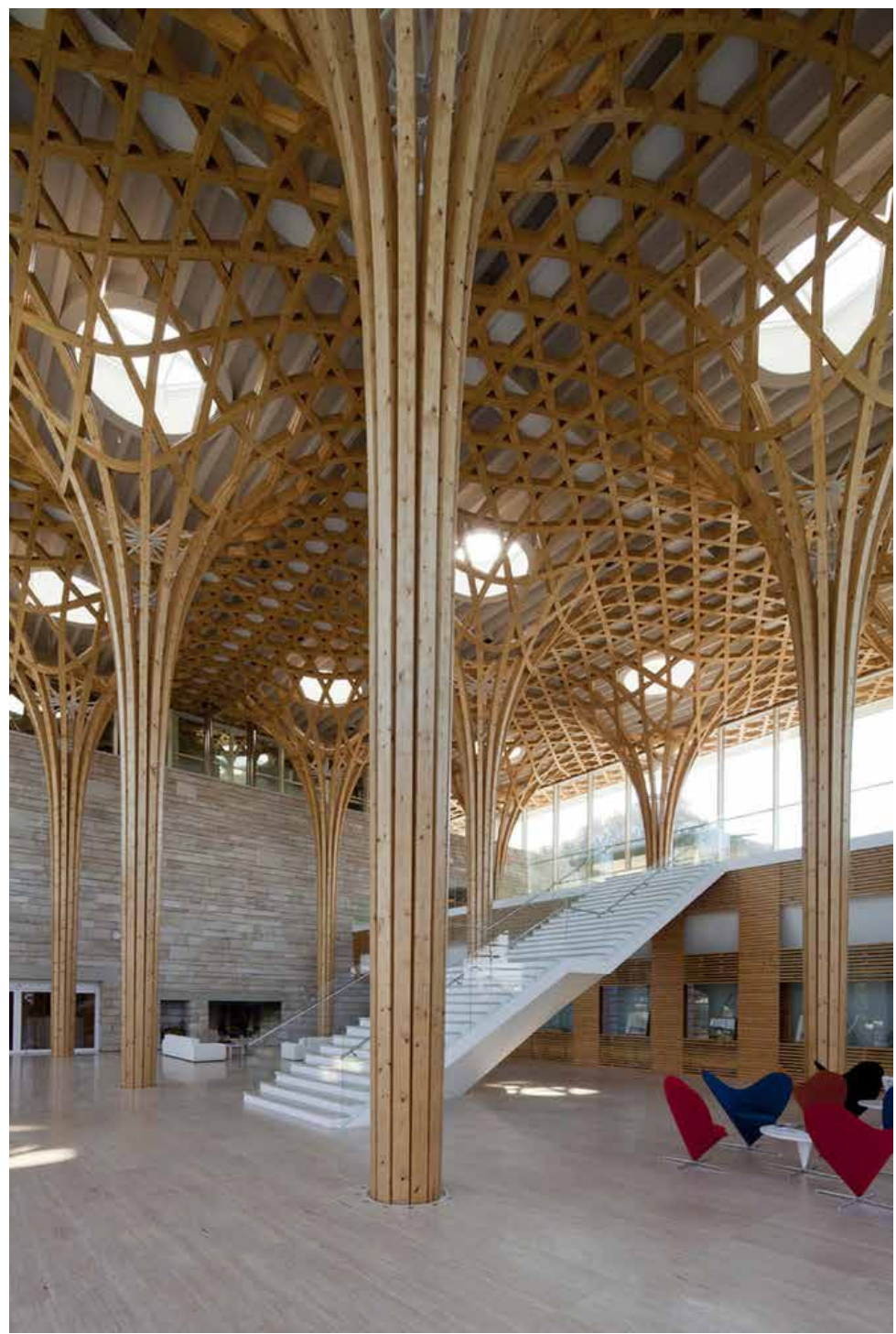

Obr. 5. Vstupní atrium objektu (Zdroj: https://www.archdaily.com/490241/nine-bridges-country-club-shigeru-ban-architects/53325859c07a806c360000aa-nine-bridges-country-club-shigeru-ban-architects-photo [cit. 2018-08-30]) 


\section{Gridshell v Trondheimu}

(experimentální stavba)

Krigsseilerplassen, Trondheim, Norsko

Norwegian University of Science and Technology, Department of Structural Engineering Steinar Hillersøy Dyvik, John Haddal Mork, Bendik Manum

2015

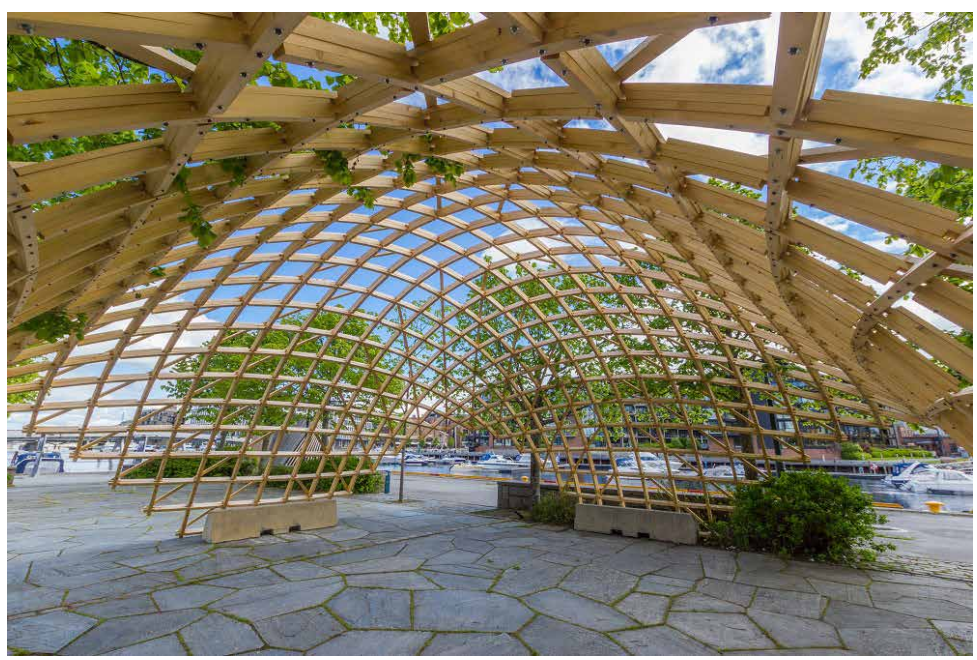

Obr. 6. Pavilon typu gridshell v Trondheimu (Zdroj: https://www.ntnu.edu/kt/research/csdg/research/trondheim-gridshell [cit. 2018-08-30])

Experimentální stavba, klasifikovaná jako pavilon na půdorysu o ploše sto metrů čtverečních, vznikla jako diplomová práce studentů norské univerzity. Výchozí myšlenkou pro návrh konstrukce bylo nalezení optimálního tvaru a konstrukce na bázi dřeva pro tento typ struktury. Studenti provedli rozsáhlou analýzu realizovaných obdobných staveb, jak z hlediska architektonického, tak konstrukčního. Na základě statických rozborů a modelů následných variantních návrhů byla modifikována výsledná forma. Tím byla nalezena forma optimálního rozložení sil, aby byly maximálně vyloučeny stř̌ihové síly a ohybové momenty. Zároveň bylo zajištěno rovnoměrné rozložení sil v ploše skořepiny, aby některá část nebyla namáhána výrazně více než jiná. Pro stavbu byla zvolena metoda vytvoření plošného rastru, který byl následně deformován zvedáním středu konstrukce se zafixovanými podporami.

Přínos na poli architektonického prostoru není natolik zásadní jako teoretická a stavebněkonstrukční část. Při proveřování statického působení různých forem byly stanoveny vhodné, nevhodné a podmínečně akceptovatelné tvary pro ohýbaný typ 
struktur gridshell. Pro vývoj formy bylo maximálně využito parametrického navrhování (program Rhinoceros s moduly Grasshopper, Kangaroo a Karamba), kde byly na základě statických výpočtů měněny vstupní parametry algoritmu. Součástí práce bylo i prověření možných spojů jednotlivých prvků, jejich výhod a nevýhod. Dále byla část věnována zkouškám vlastností jednotlivých druhů dřeva a také vlivu rozložení vláken, let a suků v průřezu stavebního prvku. Zajímavostí je finální rozpočet stavby, který dokládá vysokou ekonomičnost dřevěných struktur gridshell.

\section{Pavilon postavený na principu pop-up v rámci výzkumného projektu BOWOOSS}

(experimentální projekt)

kolektiv studentů Universität des Saarlandes

Saarbrücken, Německo

2002

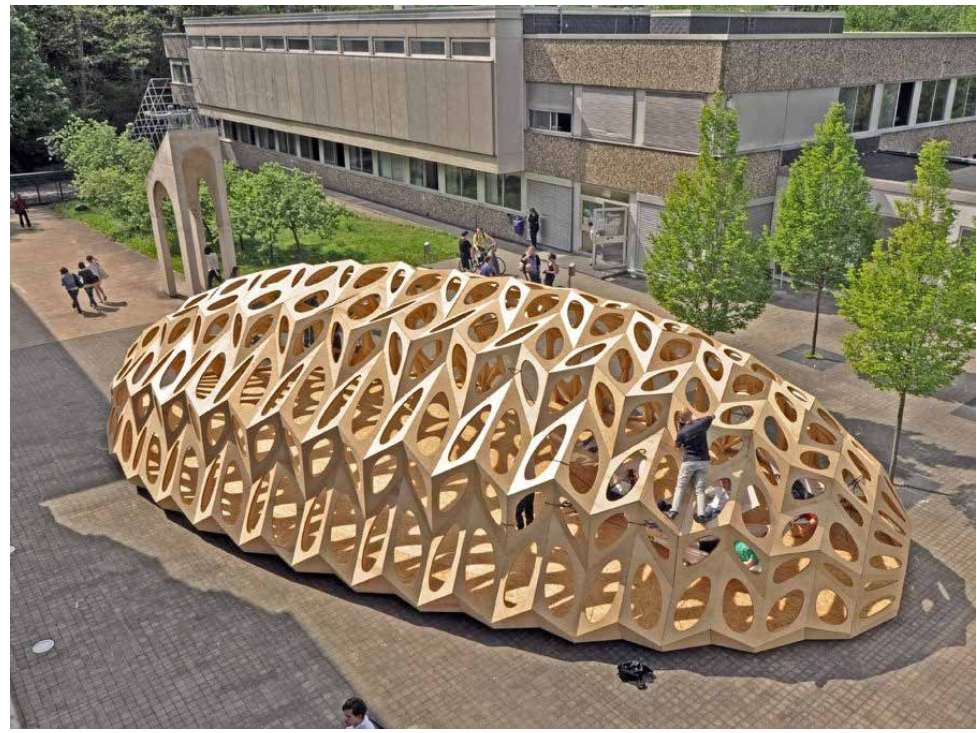

Obr. 7. Pavilon na principu pop-up (Zdroj: https://www.frameweb.com/news/pop-up-pavilion-by-bowooss-research-project [cit. 2018-08-30])

Forma skořepiny pavilonu, vytvořeného studenty architektury, vychází z biomimetického studia schránek mořského planktonu. Z konstrukčního hlediska se jedná o mezistupeň mezi klasickými skořepinami (v tomto př́padě se dá mluvit o lomenici) a strukturou gridshell, obecně by se dala konstrukce nazývat „pseudogridshell“. Materiál z jednotlivých (dvourozměrných) ploch je ve středu odstraňován, čímž zůstává hmota jen na spojovaných hranách. Jednotlivé hrany jsou navíc vyztuženy žebry kolmými na desky. Ve výsledku pak dojde k obdobnému statickému působení jako 
u roštových konstrukcí gridshell. Díky deskám je zajištěna prostorová tuhost jednotlivých segmentů, a tím i celé konstrukce.

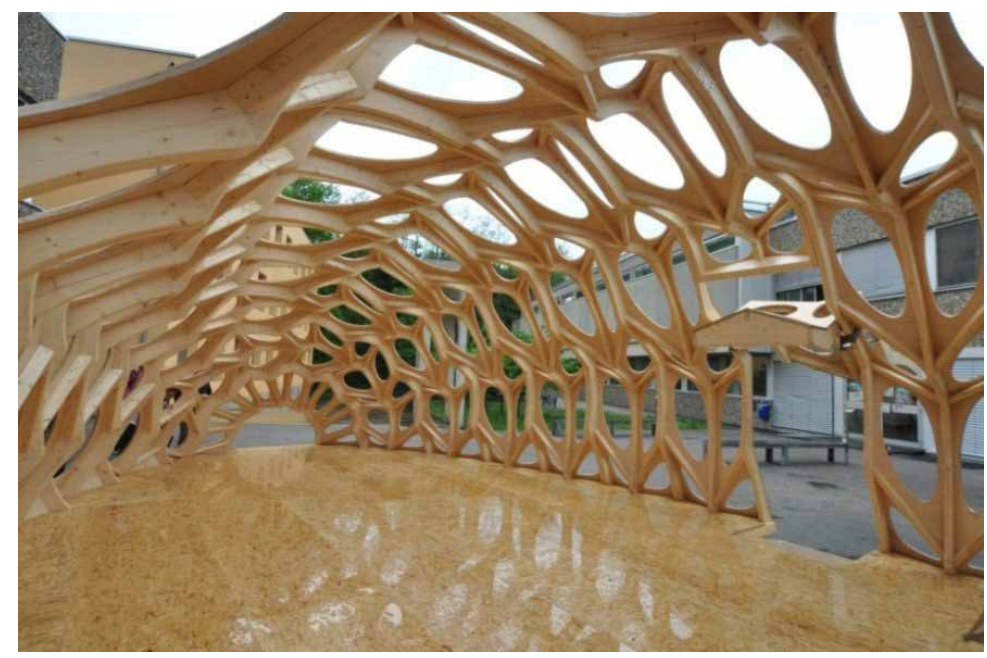

Obr. 8. Konstrukce pavilonu (Zdroj: http://www.evolo.us/bowoos-bionic-research-pavilion-is-inspired-by-marine-biodiversity [cit. 2018-08-30])

Uvnitř stavby vzniká unikátní architektonický prostor. Přestože se jedná o organickou formu, nejedná se o náhodnou „sochařskou“ záležitost, ale formu poměrně jednoduše matematicky popsatelnou. Tvar vychází z konstrukční podstaty stavby a možností dřevěných konstrukcí, čímž vzniká pro člověka snadno uchopitelný prostor. Uvnitř stavby se člověk následně cítí př́ijemně, i když oválný půdorys částečně působí problémy s prostorovou orientací. Důkazem o vzniku kvalitního architektonického prostoru bylo umístění pavilonu do veřejně přístupného území. Pavilon byl lidmi hodně využíván a následně do něj byly nainstalovány houpací sítě pro odpočinek.

\section{Závěr}

Ze závěrů analýz jednotlivých referenčních staveb lze vyvodit nové trendy v navrhování dřevěných nosných konstrukcí. Jsou to deskové a prutové systémy na principu mřížových skořepin (gridshell), jejichž tvarové a rozponové možnosti nejsou zatím vyčerpány. Dosud se jedná o pravidelné mřižové rastry, kde se rozdílné působení a zatížení bud’ neprojevují v konstrukci vůbec, nebo jsou charakterizovány zvětšením dimenzí jednotlivých prvků. Další vývoj by mohl jít směrem nepravidelných ortogonálních sítí nebo organických mřrižovin. $\mathrm{V}$ místech většího namáhání by došlo $\mathrm{k}$ nahuštění sítě a opačně. $K$ výpočtům a pravděpodobně i návrhům by bylo nutné využívat nové parametrické programy. 
Existence experimentálních dřevěných staveb dokazuje fakt, že možnosti dřeva ještě nejsou vyčerpány. Je možné vydat se cestou analogického přepisu standardních statických schémat typických pro jiný materiál do dřevěných prvků. Takových konstrukcí je mnoho a s postupujícím technologickým vývojem stále vznikají nové, které můžeme převádět do dřeva. Některé experimentální konstrukce nevykazují stoprocentní soulad hmoty a formy materiálu a výsledek následně není zcela charakteristický pro dřevo jako základní prvek. Přesto jsou tyto stavby velmi cenné při následném výzkumu a vývoji, protože představují klíčový prototyp, na jehož základě může být u další stavby nesoulad minimalizován nebo odstraněn, a dojde tak k objevení zcela nové strukturální formy.

\section{Použitá literatura}

MCLEAN, William, Peter SILVER a Peter EVANS. Structural engineering for architects. A handbook. London: Laurence King, 2014. ISBN 9781780670553.

MACDONALD, Angus J. Structure and architecture. 2. vyd. Oxford: Architectural Press, 2001. ISBN 9780750647939.

CHILTON, John, Gabriel TANG. Timber gridshells: architescture, structure and craft, 2017. ISBN 9781138775305

LAAN, Hans van der. Architectonic space: fifteen lessons on the disposition of the human habitat. Leiden: Brill, 1983. ISBN 9789004069435. 